\title{
SIMULTANEOUS DETERMINATION OF LH AND PROGESTERONE IN PERIPHERAL BOVINE BLOOD DURING PREGNANCY, NORMAL AND CORTICOID-INDUCED PARTURITION AND THE POST-PARTUM PERIOD
}

\author{
D. SCHAMS, B. HOFFMANN, S. FISCHER, E. MARZ AND H. KARG \\ Institut für Physiologie, Technische Universität München, \\ 805 Freising-Weihenstephan, Germany
}

(Received 23rd March 1971, accepted 28th September 1971)

\begin{abstract}
Summary. Levels of LH were determined by radioimmunoassay and those of progesterone by a competitive protein-binding technique. Blood samples from eight cows, representing two complete pregnancies (including post-partum periods), and from one cow in the first trimester and another around the time of parturition, were collected. The samples were withdrawn at intervals of $6 \mathrm{hr}$ for LH and every 4 to 5 days for progesterone determination. Levels of $\mathbf{L H}$ were consistently low ( 1.0 to 1.6 $\mathrm{ng} / \mathrm{ml}$ plasma) with a few single peaks occurring irregularly in individuals during the first 110 days. Distinct LH peaks were observed between Days 7 and 20 post partum. The decrease of progesterone from high levels during pregnancy (plateau between 5 and $9 \mathrm{ng} / \mathrm{ml}$ plasma with individual differences) before parturition and the low level following was not reflected in the LH concentration. In an experiment with one animal, an injection of $5 \mathrm{mg}$ flumethasone near term caused a partial decrease in the progesterone concentration, and a larger dose of $10 \mathrm{mg}$ induced parturition. This was preceded by a marked decrease of progesterone similar to that observed before a normal delivery.
\end{abstract}

\section{INTRODUGTION}

While progesterone has been determined in bovine peripheral blood during different periods of pregnancy and the post-partum period (Shemesh, Ayalon \& Lindner, 1968; Erb, Estergreen, Gomes, Plotka \& Frost, 1968; Pope, Gupta \& Munro, 1969; Stabenfeldt, Osburn \& Ewing 1970; Hoffman \& Karg, 1970), LH has been assayed in comparatively few experiments during early pregnancy (Schams, 1969; Henricks, Dickey \& Niswender, 1970). In order to draw conclusions about the relationship of LH and progesterone in vivo during pregnancy and the post-partum period, it would seem to be desirable to make frequent measurements of both hormones in identical blood samples. From incubation and perfusion experiments in connection with the exogenous administration of LH-active preparations, several authors (Wiltbank, Roth- 
lisberger \& Zimmerman, 1961; Donaldson \& Hansel, 1965; Hansel, 1967; Schomberg, Coudert \& Short, 1967; Mills \& Morrissette, 1970; Nalbandov, 1970; Hansel \& Snook, 1970) have discussed the fact that LH may exhibit some luteotrophic activity in the cow. Some indication for the luteotrophic action of endogenous LH in the cow in vivo was found by Karg, Hoffman \& Schams (1969, 1971), who measured an increase in the progesterone concentration of the peripheral blood in a few cows after short LH peaks occurring around Day 9 of the oestrous cycle; and in one case, after an extraordinary LH peak on Day 19 , followed by an extension of the cycle to 30 days. Snook, Brunner, Saatman \& Hansel (1969) showed that antibovine LH serum in vivo also had some depressant effect on CL size and progesterone concentration in the luteal tissue. We found a depletion of the peripheral progesterone level after administration of a specific antibovine LH serum during the cycle (Karg, Hoffman \& Schams, 1971). In this study, data are presented from experiments in which LH and progesterone concentrations were determined in identical plasma samples from peripheral blood of cows during pregnancy and the post-partum period.

\section{MATERIALS AND METHODS}

\section{Animals}

The animals used in the first series of the experiments were six pregnant cows (5 to 10 years old) with normal breeding histories, and two pregnant heifers; they were crossbreeds from Simmental/Holstein-Canadian races, which have an average pregnancy period of 279 days. The animals were in different periods of gestation during the collection of blood samples (January until April 1970). These samples represent two complete pregnancy periods. Progesterone was also analysed in plasma samples from another cow (Holstein): LH had been previously assayed in an earlier experiment on the same cow carried out during the first trimester of gestation (Schams, 1969). One cow of the Brown Swiss breed, with a pregnancy of normal duration of 287 days, was included from an experiment involving thirty-nine animals (Karg, Böhm, Günzler \& Müller, 1971) where parturition was induced by the injection of a glucocorticoid

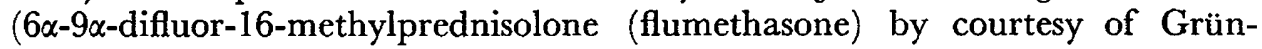
enthal/Syntex).

\section{Blood sampling}

Blood was collected daily at 6 -hr intervals $(05 \cdot 00,11.00,17.00$ and 23.00 hours $)$ from the jugular vein by venipuncture into plastic centrifuge tubes. As an anticoagulant, the heparin preparation 'Liquemin' (Hoffmann-La Roche) was used. The blood was immediately cooled on ice, centrifuged and stored at $-18^{\circ} \mathrm{C}$ until further use. All samples were evaluated for LH. Progesterone was determined, preferably in the 17.00 -hour sample, at 4- to 5-day intervals and, in a few cases, once or twice a day.

\section{Radioimmunoassay of luteinizing hormone}

Luteinizing hormone was quantified by radioimmunoassay according to the method described by Schams \& Karg (1969). For iodination, the LH preparations 
LER-791-1 and III-17-BP were used. A highly specific antiserum to LH, obtained by the immunization of rabbits, was used. This antiserum showed no cross-reaction by immunodiffusion, immunoelectrophoresis and radioimmunoassay with serum proteins and pituitary hormones (bovine prolactin (NIH-P-B ), $^{2}$ bovine growth hormone (NIH-GH-B ${ }_{10}$ ), synthetic adrenocorticotrophic hormone 1-24 (Ciba) and pure bovine thyroid-stimulating hormone) after the absorption with bull serum. Only in the high dose ranges were cross-reactions observed with HCG, PMSG or with highly purified sheep FSH (thirty-two times as active in bioassay as FSH NIH-S $)_{1}$. The antiserum was also able to neutralize the biological activity of LH estimated by the OAAD-test. Measuring serum values by radioimmunoassay and bioassay, the physiological variations were the same but the absolute values measured by bioassay were between three and ten times higher than those measured by radioimmunoassay (Karg, Schams \& Böhm, 1969).

That the assay is suitable to measure LH in bovine blood is established by the parallel shape of the dilution curves of LH added to bovine plasma, and of endogenous LH compared with the standard curves. The results from LH recovery experiments (Schams \& Karg, 1970) also confirm the suitability of the assay method. All results were expressed in terms of ng LH-LER-791-1/ml plasma, which is equivalent to $1 \cdot 1$ times LH-NIH-s. ${ }_{1}$. The antibody-bound hormones were separated from the free labelled hormone by centrifugation. All plasma samples were run in duplicate with 0.2 or $0.3 \mathrm{ml}$ plasma per test tube and each peak was re-examined. The minimum detectable value in this assay system was $0.5 \mathrm{ng} / \mathrm{ml}$ serum or plasma.

\section{Determination of progesterone}

Progesterone was determined in bovine peripheral plasma by the competitive protein-binding method (Hoffmann \& Karg, 1970). For the exact calculation of recovery in individual samples, this method was further improved by applying internal standardization which was similar to that used in the method published by Reeves, de Souza, Thompson \& Diczfalusy (1970). A small amount of $\left[{ }^{3} \mathrm{H}\right]$ progesterone (2500 disintegrations/min) of high specific activity (progesterone la,2a-T(n), $41 \mathrm{Ci} / \mathrm{mmol}$, the Radiochemical Gentre, Amersham) was pipetted as internal standard into the extraction tube and dried down in a stream of nitrogen at $40^{\circ} \mathrm{C}$ before the addition of $1 \mathrm{ml}$ plasma. Following the extraction procedure and thin-layer chromatography, the sample was taken up in $1 \mathrm{ml}$ methanol and the recovery-generally between 60 and $70 \%$-was determined from the disintegration $/ \mathrm{min}$ rate measured in a $0.1-\mathrm{ml}$ aliquot. To compensate for the remaining counts in the sample used for the protein-binding reaction, two-thirds of the amount of $\left[{ }^{3} \mathrm{H}\right]$ progesterone used as internal standard were added to each point of the standard curve.

\section{RESULTS}

The results of the $\mathrm{LH}$ and progesterone determinations on the peripheral plasma from the eight animals, samples from which represented two complete pregnancy periods, are shown in Text-figs. 1 and 2. Each point for LH in these figures represents an average value of twenty plasma samples from 5 con- 
D. Schams et al.

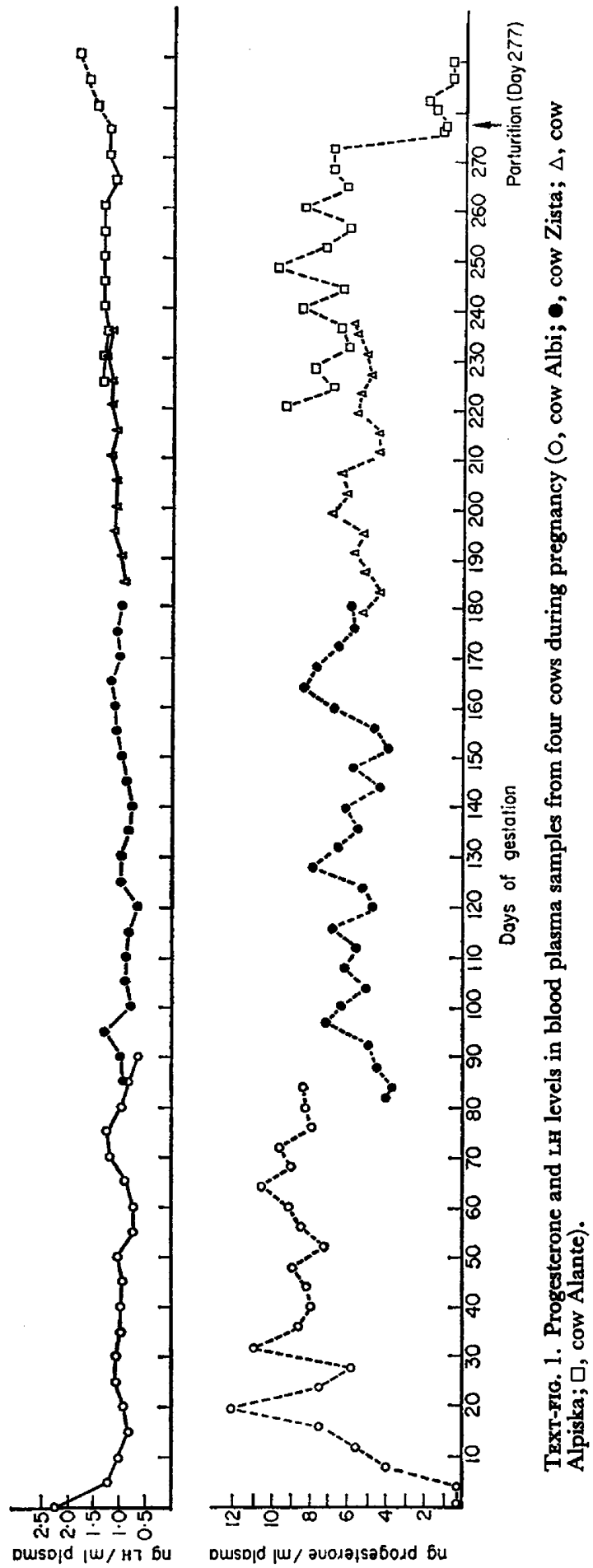




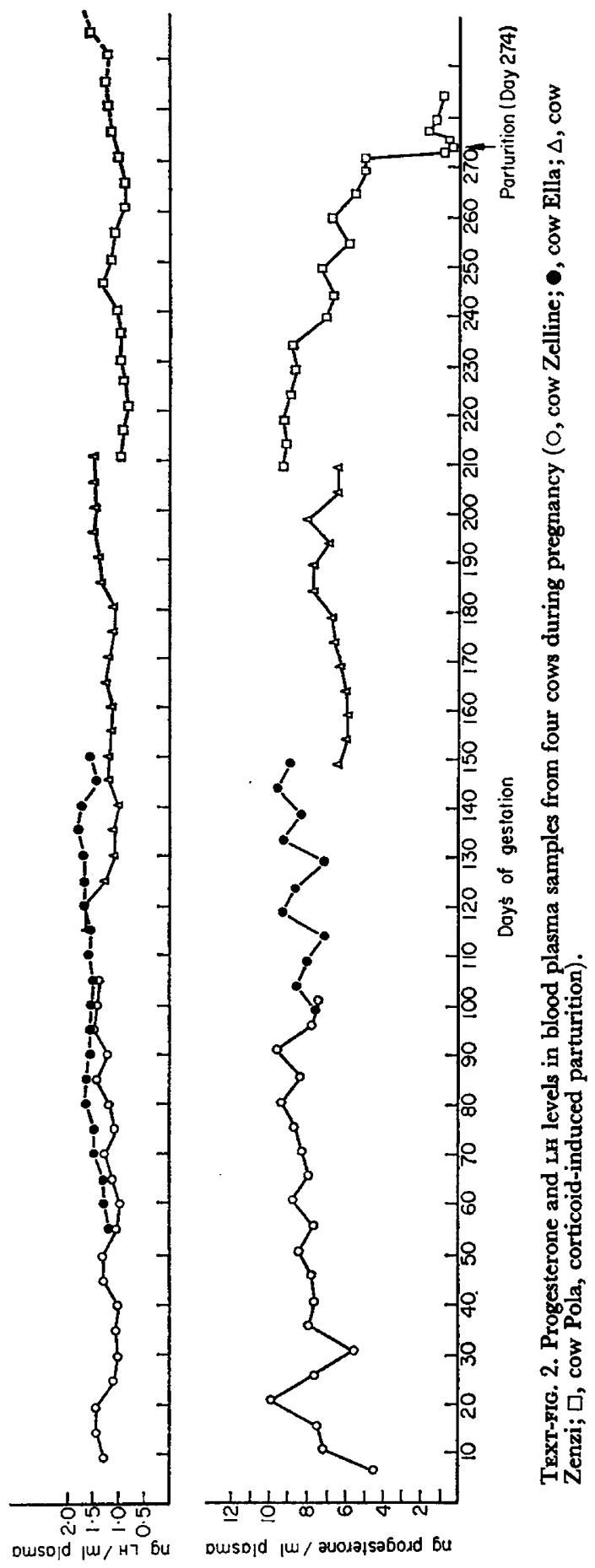


secutive days. In general, the LH levels range around $1 \mathrm{ng} / \mathrm{ml}$ plasma throughout the whole pregnancy period. The mean values for each cow, calculated from all samples measured, are shown in Table 1. Only in one cow (Zista) were small LH peaks observed on Day 94 and Day 103 (see Text-fig. 3). In this cow, progesterone was determined twice a day but the concentrations of both

TABLE 1

MEAN VALUES OF LH IN PERIPHERAL BOVINE BLOODPLASMA FROM COWS IN DIFFERENT PERIODS OF PREGNANCY

\begin{tabular}{l|c|c|c}
\hline $\begin{array}{c}\text { Name of } \\
\text { cow }\end{array}$ & $\begin{array}{c}\text { Pregnancy period } \\
\text { (days of gestation })\end{array}$ & $\begin{array}{c}\text { Mean LH values } \\
(\text { ng/ml plasma })\end{array}$ & No. of samples \\
\hline Albi & 12 to 89 & $1 \cdot 0 \pm 0.34$ & 357 \\
Zista & 82 to 180 & $0 \cdot 96 \pm 0 \cdot 28$ & 391 \\
Alpiska & 179 to 237 & $1 \cdot 13 \pm 0 \cdot 20$ & 233 \\
Alante & 220 to 276 & $1 \cdot 30 \pm 0 \cdot 24$ & 231 \\
Zelline & 7 to 105 & $1 \cdot 24 \pm 0 \cdot 27$ & 394 \\
Ella & 51 to 149 & $1 \cdot 56 \pm 0 \cdot 25$ & 394 \\
Zenzi & 111 to 209 & $1 \cdot 30 \pm 0 \cdot 27$ & 394 \\
Pola & 206 to 274 & $1 \cdot 04 \pm 0 \cdot 20$ & 275 \\
\hline
\end{tabular}
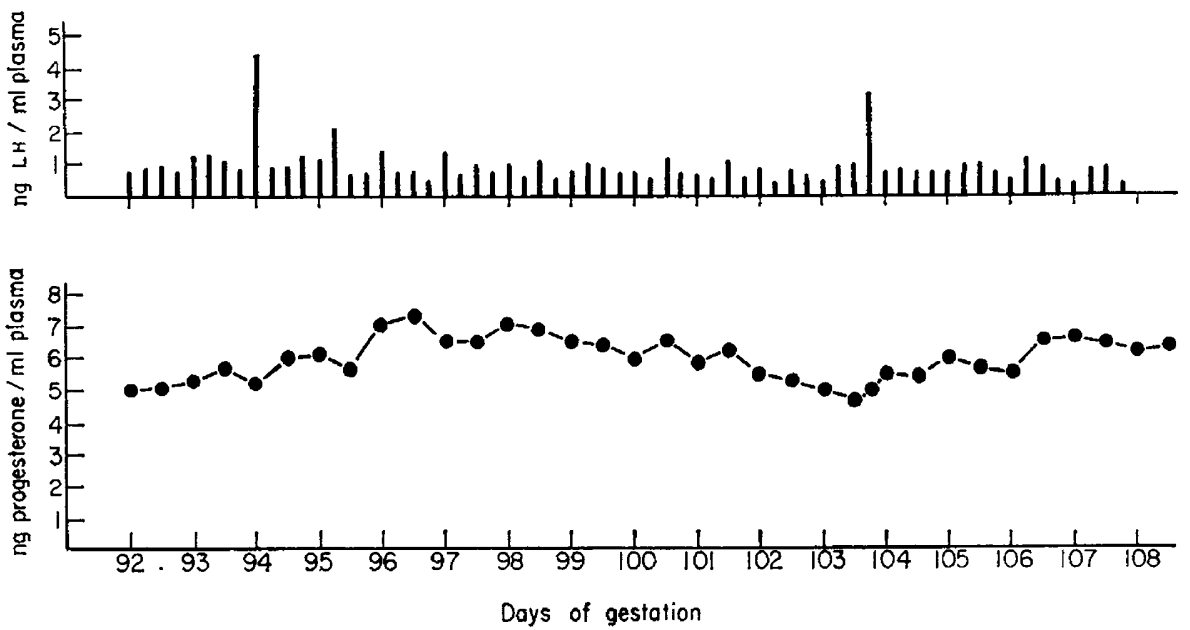

TeXT-FIG. 3. Progesterone-LH relationship in peripheral blood plasma of one cow (Zista) from Days 92 to 108 of gestation.

hormones did not seem to be correlated. In another cow, where an LH peak on Day 52 was observed (Schams, 1969), progesterone was consistently highbetween 6.3 and $8.4 \mathrm{ng} / \mathrm{ml}$ plasma.

Progesterone values increased at the beginning of pregnancy with the development of the CL. After reaching maximal levels on Days 20 and 21, a slight drop was observed. The change from the CL of the normal cycle to the CL of pregnancy was characterized by progesterone values higher than $5 \mathrm{ng} / \mathrm{ml}$ plasma during Days 18 to 24 . Allowing for individual variations, the concentration seems to 


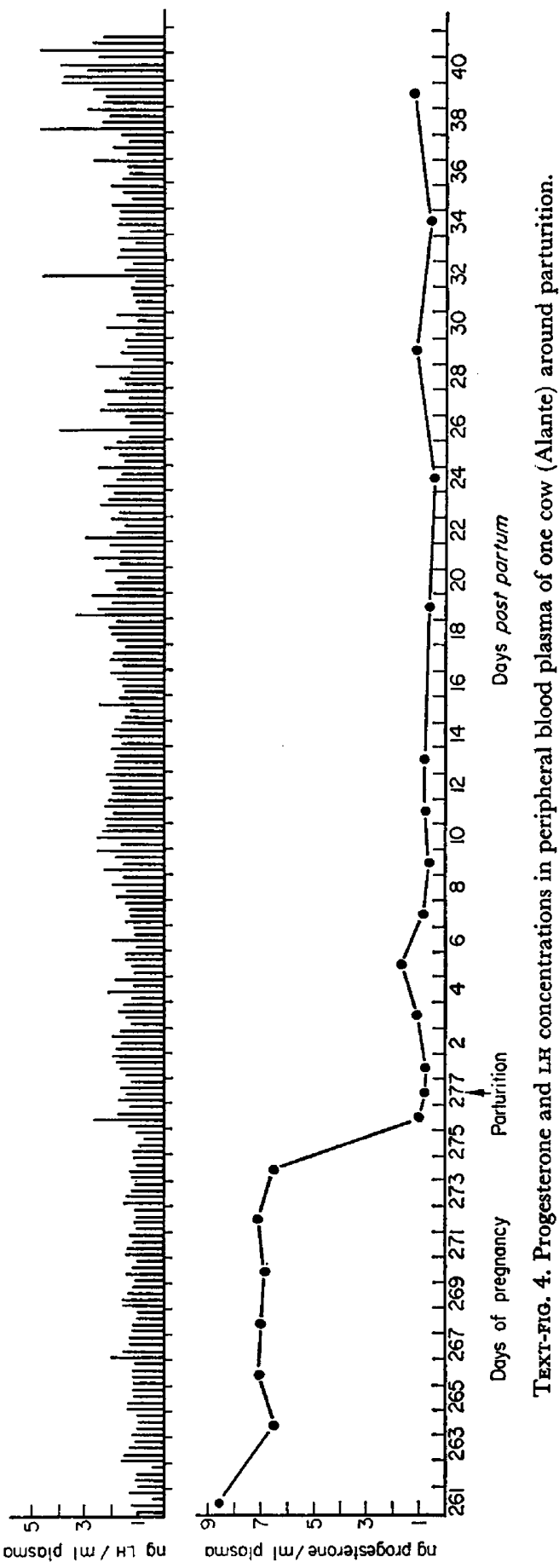




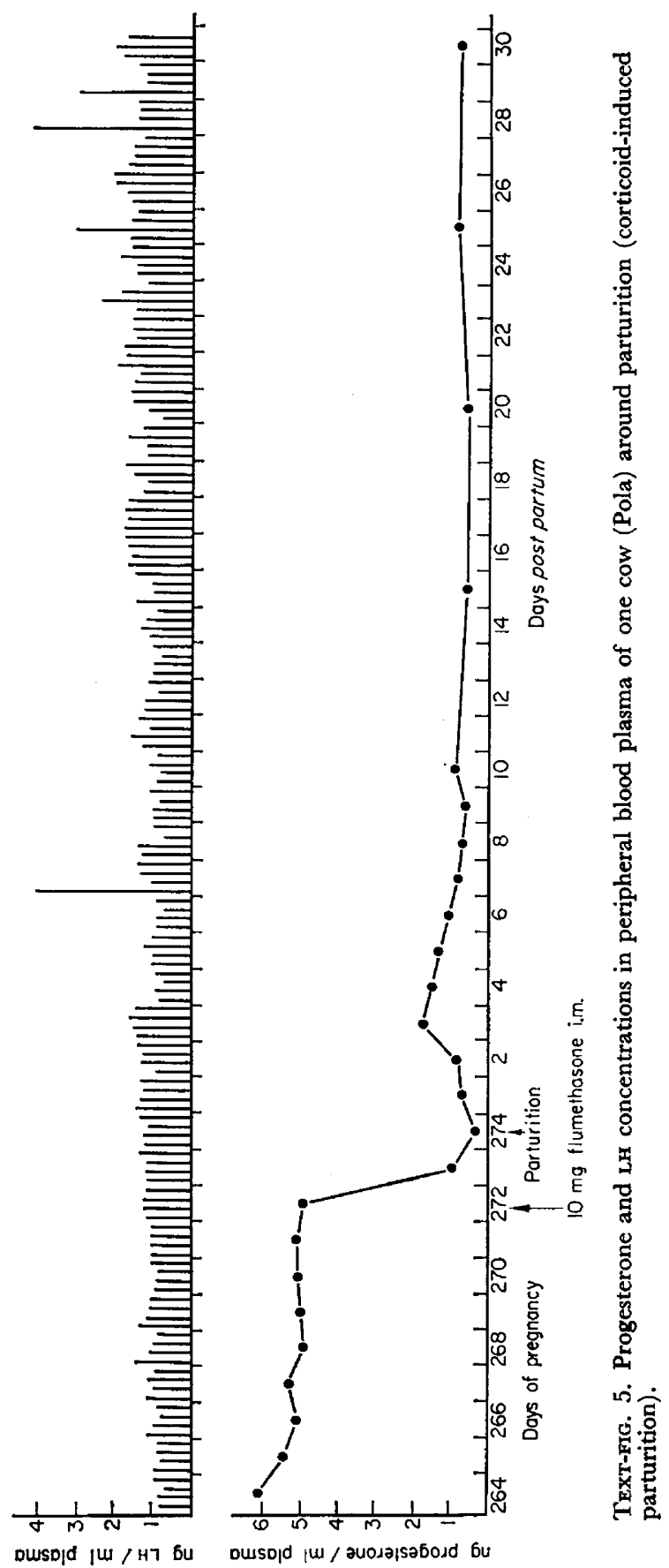


remain fairly constant after Day 40 but shows a tendency to decrease after Day 240 . It then drops markedly within the 2 days preceding parturition. By the time that parturition occurs, minimum progesterone levels have already been reached (Text-figs. 4 and 5).

No change in the progesterone concentration was observed during the post-partum period up to 30 to 39 days following parturition. No significant alteration in LH occurred before, during and for a few days after parturition. In the data shown in Text-fig. 4, some small irregularly occurring LH peaks showed up around Day 20 post partum. No oestrus was observed during that time. In the data shown in Text-fig. 5, the first small LH peaks were observed

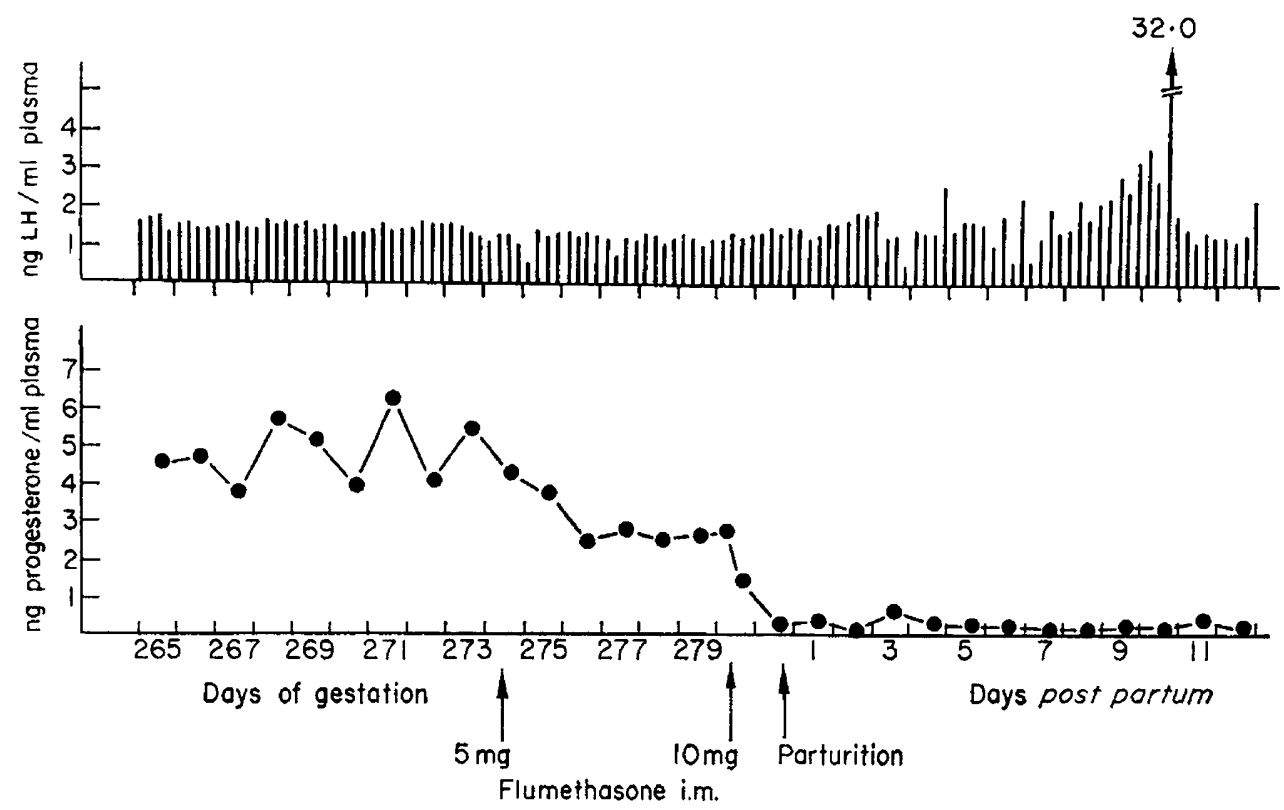

TexT-FIG. 6. Progesterone and LH concentrations in peripheral blood plasma of one cow (Bruni) before and after 5-mg and 10-mg injections of flumethasone to induce parturition.

on Days 7 and 28 following parturition. This cow was treated on Day 272 of pregnancy with $10 \mathrm{mg}$ flumethasone for the initiation of parturition which occurred 2 days later.

In another animal with an expected duration of pregnancy of 287 days (Text-fig. 6), the first attempt to induce parturition was made on Day 274 with the low dose of $5 \mathrm{mg}$ flumethasone and later on Day 280 with an effective dose of $10 \mathrm{mg}$ of the same compound. The first injection was followed by a decrease in the progesterone level from around $6 \mathrm{ng} / \mathrm{ml}$ plasma to approximately 3 $\mathrm{ng} / \mathrm{ml}$. During the parturition induced with the second injection of flumethasone, no differences occurred in the decline of progesterone and in the basic levels of LH compared to the occurrence during a normal delivery. In this cow, the distinct first LH peak of $32 \mathrm{ng} / \mathrm{ml}$ plasma on Day 11 post partum was most obvious. 


\section{DISGUSSION}

Our results in the cow clearly demonstrate the presence of low LH levels throughout the whole period of pregnancy. Progesterone values show the characteristic rise at the beginning and the decline at the end of the gestation period, with a plateau in between. The absolute values differ individually. The constant levels of progesterone through the gestation period until the approach of term, do not support the theory of a change in the source of progesterone during the last trimester of pregnancy (see Stabenfeldt $e t$ al., 1970). Since both hormones showed completely different secretion patterns, it seemed meaningless-at least during the pregnancy period and the post-partum phase-to apply statistical methods for correlation. It seems that progesterone secreted during pregnancy effectively prevents LH release in most individuals, though in our experiments, in the case of one cow (Zista), single LH peaks around Days 94 and 103 of gestation appeared (Text-fig. 3). Similar observations were described earlier by Schams (1969) and Karg \& Schams (1970) for other cases during the first trimester. In this connection, it may be pointed out that, in the normal bovine oestrous cycle in addition to the distinct LH peak before ovulation, and extraordinary LH peak can occur during the early CL phase in some individuals. This was first demonstrated by Schams \& Karg (1969) and Karg \& Schams (1970) during multiple blood-sampling periods of four to six times a day.

The extraordinary LH peaks observed in this study during pregnancy did not show an obvious correlation with the progesterone level preceding or following these peaks, probably because the progesterone level already had its 'pregnancy plateau'. Moreover if, according to the in-vitro perfusion studies of Mills \& Morrissette (1970) with bovine ovaries, LH seems to be luteotrophic during the early and late phases of pregnancy, our endogenous LH data clearly showed that the decrease of progesterone levels near term was not accompanied by diminished $\mathbf{L H}$ values.

It may be concluded that, in the cow, the demonstration of a luteotrophic action of LH may occur in certain situations, for instance in the presence of active luteal tissue with a low progesterone synthesis rate, provided that there is no dominance of any possible luteolytic activity. The decline of progesterone near term is not due to a lack of $\mathrm{LH}$, so other factors have to be considered to luteolyse and hence, to initiate parturition. The well-known rise of oestrogen secretion, particularly at the end of pregnancy (Erb, Randell, Mellin \& Estergreen, 1968; Grunert \& Ahlers, 1969; Robinson, Baker, Anastassiadis \& Common, 1970), seems not to alter significantly the LH secretion rate. Further experimental evaluation is needed in order to explain why the basic level of LH in the peripheral blood of the cow also remains so constant around the time of parturition, when major changes in hormonal relationships are known to occur. This is especially remarkable since it was found earlier (Karg, 1966, $1967 \mathrm{a}, \mathrm{b})$ that pituitary glands of new-born calves showed depleted LH concentrations.

The interesting observation that progesterone levels decrease after the administration of a glucocorticoid, gives an indication of a possible mechanism 
involved in luteolytic action near term. The LH and progesterone secretion patterns following administration of the glucocorticoid show that this treatment simulates the naturally occurring events, at least those involving the function of these hormones around parturition. During the post-partum period, a distinct LH peak was first observed on Day 7 in one cow and a more distinct one on Day 11 in another cow. It seemed, at least in this early post-partum phase, that many individual differences are apparent in the re-establishment of the oestrous cycle, probably due to the irregular release pattern of LH. After these early peaks, progesterone levels still remained low and it was concluded that neither ovulation nor luteinization occurred.

The blood levels of $\mathrm{LH}$ and progesterone appear to reflect two rather different release patterns suggesting that the relationship of these hormones under different physiological conditions require very careful interpretation.

\section{AGKNOWLEDGMENTS}

This work was supported by the Deutsche Forschungsgemeinschaft. We also acknowledge gratefully the supply of $\mathrm{LH}$ standard preparations from the National Institutes of Health, Bethesda, from Dr L. E. Reichert (LH-LER-791-1), Atlanta and Dr H. Papkoff (LH-no.III-17-BP), San Francisco. The pure bovine TSH preparation was kindly supplied by Dr Pierce, Los Angeles.

\section{REFERENCES}

Donaldson, L. E. \& Hanser, W. (1965) Prolongation of life span of the bovine corpus luteum by single injections of bovine luteinizing hormone. F. Dairy Sci. 48, 903.

Erb, R. E., Estergreen, V. L., JR, Gomes, W. R., Plotka, E. D. \& Frost, O. L. (1968) Progestin levels in corpora lutea and progesterone in ovarian venous and jugular vein blood plasma of the pregnant bovine. 7. Dairy Sci. 51, 410.

ERB, R. E., Randel, R. D., Melin, T. N. \& Estergreen, V. L., JR (1968) Urinary estrogen excretion rates during pregnancy in the bovine. 7. Dairy Sci. 51, 416.

Grunert, E. \& Ahlers, D. (1969) Harnöstrogenbestimmung beim Rind zur Diagnose intra-uterin abgestorbener Früchte. Dt. tierärztl. Wschr. 76, 497.

HANsEL, W. (1967) Studies on the formation and maintenance of the corpus luteum. In: Reproduction in the Female Mammal, p. 346. Eds. G. E. Lamming and E. C. Amoroso, Butterworth, London.

Hansel, W. \& Snoox, R. B. (1970) Pituitary ovarian relationships in the cow. F. Dairy Sci. 53, 945.

Henricks, D. M., Dickey, J. F. \& Niswender, G. D. (1970) Serum luteinizing hormones and plasma progesterone levels during the estrous cycle and early pregnancy in cows. Biol. Reprod. 2, 346.

HofrmanN, B. \& KARG, H. (1970) Determination of progesterone in bovine peripheral plasma by competitive protein binding. Annls Endocr. 31, 823.

KARG. H. (1966) Bestimmung des Interstitialzellen stimulierenden Hormones (ICSH) in Hypophysen von Rinderfoeten. Naturwissenschaften, 53, 41.

KARG. H. (1967a) Studies on the LH-content in the pituitary and the androgens in the testes of the bovine foetus. In: Reproduction in the Female Mammal, p. 239. Eds. G. E. Lamming and E. C. Amoroso, Butterworth, London.

KARG, H. (1967b) Untersuchungen über das gonadotrope Hypophysenhormon LH (ICSH) während der Entwicklung beim Rind. Zuchthygiene, 2, 12.

KaRG, H., BöHM, S., GüNzleR, O. \& MülleR, S. (1971) Erfahrungen über die Geburtseinleitung beim Rind mit Glukokortikoiden. Dt. tierärztl. Wschr. 78, 25.

Karg, H., Hoffmann, B. \& Schams, D. (1969) Verlauf der Blutspiegel an Progesteron, Luteinisierungshormon und Prolaktin während des Zyklus bei einer Kuh. Zuchthygiene, 4, 149.

Karg, H., HoffmanN, B. \& Schams, D. (1971) LH-, prolactin- and progesterone-relationship in vivo (data from the bovine). 3rd Intern. Congr. on Hormonal Steriods, Hamburg, Excerpta med. Fdn, ICS, (in press).

KARG, H. \& SCHAMS, D. (1970) Comparative aspects of pituitary regulatory pattern of sexual functions. In: Mammalian Reproduction, p. 88. Eds. H. Gibian and E. J. Plotz. Springer, Berlin. 
KARG, H., Schams, D. \& BöHM, S. (1969) Vergleich von radioimmunologischen und biologischen LH-Bestimmungen im Rinderblut. 15. Symp. Dtsch. Ges. für Endokrinologie, p. 324. Springer, Berlin.

Mills, R. C. \& Morrissette, M. C. (1970) Progesterone synthesis by perfused bovine ovaries of early and late pregnancy. 7 . Reprod. Fert. 22, 435.

Nalbandov, A. V. (1970) Comparative aspects of corpus luteum function. Biol. Reprod. $2,7$.

Pope, G. S., Gupta, S. K. \& Munro, I. B. (1969) Progesterone levels in the systemic plasma of pregnant, cycling and ovariectomized cows. 7. Reprod. Fert. $20,369$.

Reeves, B. D., De Souza, M. L. A., Thompson, I. E. \& Diczfalusy, E. (1970) An improved method for the assay of progesterone by competitive protein binding. Acta endocr., Copenh. 63, 225.

Robinson, R., Baker, R. D., Anastassladis, P. A. \& Common, R. H. (1970) Estrone concentrations in the peripheral blood of pregnant cows. 7. Dairy Sci. 53, 1592.

Schams, D. (1969) Radioimmunologische Bestimmung des Luteinisierungshormons (LH) im Blutserum von Kühen in den ersten zwei Monaten der Trächtigeit. Dt. tierärztl. Wschr. 76, 561.

SCHAMs, D. \& KARG, H. (1969) Radioimmunologische LH-Bestimmung im Blutserum vom Rind unter besonderer Berücksichtigung des Brunstzyklus. Acta endocr., Copenh. 61, 96.

Schams, D. \& Karg, H. (1970) Studien über die Spezifität des Radioimmunotests zur Bestimmung des Luteinisierungshormons im Rinderblut. Hoppe-Seyler's Z. physiol. Chem. 351, 41.

Schomberg, D. S., Coudert, S. P. \& Short, R. V. (1967) Effects of bovine luteinizing hormone and human chorionic gonadotrophin on the bovine corpus luteum in vivo. 7. Reprod. Fert. 14, 277.

Shemesh, M., Ayalon, N. \& Lindner, H. R. (1968) Early effect of conceptus on plasma progesterone level in the cow. 7. Reprad. Fert. 15, 161.

Snook, R. B., Brunner, M. A., SaAtman, R. R. \& Hansel, W. (1969) The effect of antisera to bovine LH in hysterectomized and intact heifers. Biol. Reprod. 1, 49,

Stabenfeldt, G. H., Osburn, B. I. \& Ewing, L. L. (1970) Peripheral plasma progesterone levels in the cow during pregnancy and parturition. Am. 7. Physiol. 218, 571.

Wiltbank, J. N., Rothlisberger, J. A. \& Zimmerman, D. R. (1961) Effect of human chorionic gonadotrophin on maintenance of the corpus luteum and embryonic survival in the cow. 7 . Anim. Sci. 20, 827. 